GLOBAL CITIZENSHIP EDUCATION 
This page intentionally left blank 


\section{Global Citizenship Education}

Challenges and Successes

EDITED BY EVA ABOAGYE AND S. NOMBUSO DLAMINI

UNIVERSITY OF TORONTO PRESS Toronto Buffalo London 
(C) University of Toronto Press 2021

Toronto Buffalo London

utorontopress.com

Printed in the U.S.A.

ISBN 978-1-4875-0637-7 (cloth)

ISBN 978-1-4875-3398-4 (EPUB)

ISBN 978-1-4875-3397-7 (PDF)

\section{Library and Archives Canada Cataloguing in Publication}

Title: Global citizenship education: Challenges and successes / edited by

Eva Aboagye and Nombuso Dlamini.

Names: Aboagye, Eva, 1957- editor. | Dlamini, S. Nombuso, 1962- editor.

Description: Includes bibliographical references and index.

Identifiers: Canadiana (print) 20200370634 | Canadiana (ebook) 20200370707 |

ISBN 9781487506377 (cloth) | ISBN 9781487533984 (EPUB) |

ISBN 9781487533977 (PDF)

Subjects: LCSH: Education and globalization. | LCSH: International

education. | LCSH: World citizenship - Study and teaching.

Classification: LCC LC191.G56 2021 | DDC 370.116-dc23

This book has been published with the help of a grant from the Federation for the Humanities and Social Sciences, through the Awards to Scholarly Publications Program, using funds provided by the Social Sciences and Humanities Research Council of Canada.

University of Toronto Press acknowledges the financial assistance to its publishing program of the Canada Council for the Arts and the Ontario Arts Council, an agency of the Government of Ontario.

Canada Council for the Arts
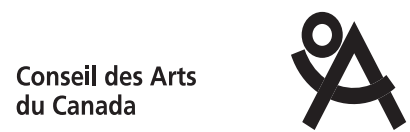

ONTARIO ARTS COUNCIL CONSEIL DES ARTS DE L'ONTARIO

an Ontario government agency un organisme du gouvernement de l'Ontario

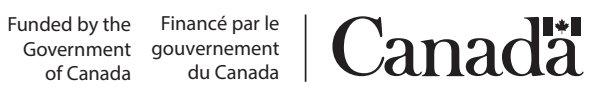

